\title{
COMPARISON OF THERAPEUTIC EFFECTS OF DIFFERENT METHODS OF ADMINISTRATION OF MEZENCHIMAL STEM CELLS TO MICE WITH PREMATURE OVARIAN INSUFFICIENCY*
}

\author{
Kozub M. I. ${ }^{1}$, Skybina K. P. ${ }^{1}$, Musatova I. B. ${ }^{2}$, Prokopiuk O. V. ${ }^{1}$, \\ Gramatiuk S. M. ${ }^{1}$, Tynynyka L. M. ${ }^{3}$, Kozub M. M. ${ }^{1}$, \\ Taran A. V. ${ }^{4}$, Nikolchenko A. Yu. ${ }^{3}$, Prokopiuk O. S. ${ }^{2}$ \\ ${ }^{1}$ Kharkiv Medical Academy of Post-Graduate Education, Kharkiv, Ukraine; \\ ${ }^{2}$ Institute for Problems of Cryobiology and Cryomedicine NAS of Ukraine, Kharkiv, Ukraine; \\ ${ }^{3}$ Private institution of higher education "Kharkiv international medical university", Kharkiv, Ukraine; \\ ${ }^{4}$ National University of Pharmacy, Kharkiv, Ukraine \\ bhbyfq@gmail.com
}

Premature ovarian insufficiency (POI) was a condition of female hypogonadism that can be caused by antitumor chemotherapy or surgery [1]. POI was observed in $1 \%$ of women under 40 years and $0,1 \%$ is up to 30 years [2], of which $37 \%$ were due to iatrogenic (mainly after treatment of oncopathology) causes [3], accompanied by numerous complications: lack of fertility, amenorrhea, psycho-emotional disorders, osteoporosis, increased mortality from cardiovascular disease and stroke [4].

Most effective method of treatment of POI was hormone replacement therapy, which, however, had a number of side effects, was requires constant use of drugs, did not recover fertil- ity and correction of pathological changes in target organs. Therefore, the search for alternative treatments based on the use of mesenchymal stem cells (MSCs) is promising: MSCs can stimulate and restore ovarian function, positively affecting folliculogenesis, preventing apoptosis, regulating the level of ovarian hormones [1]. The therapeutic potential of MSCs included their ability to differentiate with replacement of damaged cells, as well as the effect on the immediate microenvironment of the cell, secretion of various growth factors, stimulation of endogenous MSCs and progenitor cells, targeted migration of leukocytes and monocytes to the site of injury [5].

* The research was carried out as part of investigation work at the Kharkiv Medical Academy of Post-Graduate Education «Experimental substantiation and clinical application of biotechnological drugs in the restoration of fertility in patients of reproductive age during endoscopic treatment of the uterus and appendages» (State registration number: 0118 U000316).

Institution, which financed the research: Ministry of Health of Ukraine.

The authors assume responsibility for the published work.

The authors guarantee absence of competing interests and their own financial interest when carrying out the research and writing the article.

The manuscript was received by the editorial staff 28.12.2020. 
An alternative bone marrow source of MSCs for transplantation and tissue engineering is adipose tissue (AT), which could be obtained in significant quantities by cosmetic liposuction [6]. The study of the therapeutic effects of placental derivatives and intraperitoneal administration of AT MSCs in the recovery of sexual function in mice with a chemotherapy-induced POI model had been shown that complete recovery of sexual function did not occur [4]. Therefore, the search for a more effective method for the treatment of POI using the intraovarial route of administration of AT MSCs was continued. Previously, the positive effect of cell and tissue therapy on zoosocial behavior, anxiety, and the level of adaptation of mice to stress associated with the level of estrogens and their inhibitory effect on the central nervous system (CNS) had been shown [7]. Thus, the study of behavioral responses could provide indirect information about recovery of estrogen production in the body of POI mice after treatment with AT MSCs.

The aim of work was to compare the therapeutic effects of AT MSCs with intraperitoneal and intraovarial administration in recovery of sexual function and behavioral responses in mice with chemotherapy-induced POI.

\section{MATERIALS AND METHODS}

Laboratory animals were kept in according to the rules for the equipment and maintenance of the vivarium. We used 60 female 6 -monthold $\mathrm{BALB} / \mathrm{c}$ mice with a regular estrous cycle, weighting $20,2 \pm 0,4 \mathrm{~g}$, which were divided into 4 groups, 15 individuals in each group: 1 - control group, 2 - POF model without treatment, 3 - POI model and treatment of AT MSCs 100000 cells intraperitoneally once, 4 - POI model and treatment of AT MSCs 50000 cells intraovarially in each ovary. POI was simulated by the method described by Xiao G.Y. et al. [8], by administering Cyclophosphamide in a dose of $200 \mathrm{mg} / \mathrm{kg}$ (Baxter Oncology, Germany) and Busulfan (Aspen Phar$\mathrm{ma}$, Germany) in a dose of $20 \mathrm{mg} / \mathrm{kg} .200 \mathrm{mg}$ of Cyclophosphamide was dissolved in $20 \mathrm{ml}$ of Phosphate-buffered saline (PBS), $20 \mathrm{mg}$ of Busulfan was dissolved in $2 \mathrm{ml}$ of Dimethyl sulfoxide (DMSO) was added, and $0,5 \mathrm{ml}$ of each animal was injected intraperitoneally. AT MSCs were obtained according to the method of Sun M. et al. [9]. MSCs of the 3rd passage were used for administration to animals. Treatment was started 2 weeks after the administration of chemotherapy drugs. The dynamics of the weight of animals; ovarian function by vaginal cytology; sexual function by counting the number of vaginal plugs were investigated. 5 animals per group were taken out of the experiment with histological examination of preparations of the ovaries and uterus 3 weeks after chemotherapy. Histological examination of sections stained with hematoxylin-eosin was carried out for morphological assessment of organs using a Delta Optical NIB-100 microscope (Delta Optical, Poland) and ToupView V 3.7 software (Hangzhou ToupTek Photonics Co. Ltd, Hangzhou, China). 6-month-old males of the $\mathrm{BALB} / \mathrm{c}$ line were kept with females in
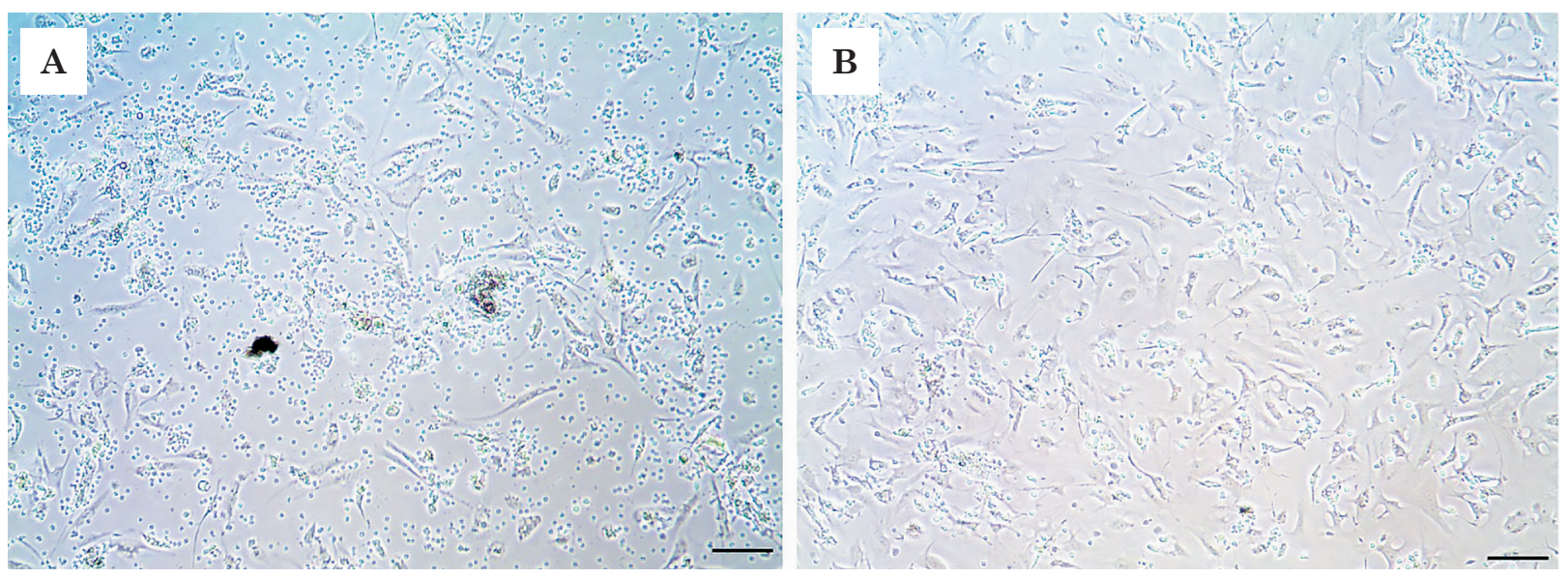

Fig. 1. Culture of AT MSCs.

a - primary passage, $\mathrm{b}$ - 3rd passage, before the injection. Scale bars $100 \mu \mathrm{m}$. 
a ratio of individuals $1: 3$ for estimation of sexual and reproductive function. The quality of life of animals was evaluated using anxiolytic and zoosocial tests, reflecting the degree of anxiety and the ability of animals to zoosocial interaction, respectively [10].

The data were statistically processed using the Mann-Whitney nonparametric U-test and the Past V.3.15 software (University of Oslo,
Norway). All stages of the study were performed in according to the European Convention for the Protection of Vertebrate Animals used for Experimental and Other Scientific Purposes 86/609/EEC and the regulations of the Ethics Committee of the Institute for Problems of Cryobiology and Cryomedicine of the National Academy of Sciences of Ukraine.

\section{RESULTS AND DISCUSSION}

Primary culture of mouse fat cells at primary passage was polymorphic cells that form separate colonies with active proliferation (Fig. 1, a), the number of which were increased from $3 \times 10^{4}$ to $8 \times 10^{4}$ cells per $1 \mathrm{~cm}^{3}$ of culture dishes during two days of cultivation (Fig. 1, b).

The study of the dynamics of the body weight of mice showed that within 8 weeks the weight of animals in the control group was increased from $20,2 \pm 1,1$ to $22,5 \pm 1,8 \mathrm{~g}$ (Fig. 2, a, group 1), in the POI model the weight of the animals was decreased up to $16,5 \pm 1,2 \mathrm{~g}$ followed by slow recovery. Their physical condition and appearance also was changed, physical inactivity, matted hair, and dull eyes were observed. Group of mice without treatment regained weight to the level of the intact group during 8 weeks. The weight of the animals, which were injected intraperitoneally with AT MSCs, was recovered on the $6^{\text {th }}$ week after chemotherapy, with intraovarial administration was on the $5^{\text {th }}$ week respectively. (Fig. 2, a, group 4). At the same time, the general condition and appearance of the animals were improved. A regular cycle was observed in all animals during investigation the estrous cycle in the control group (Fig. 2, b).

Surface epithelium was absent in the smears of mice with the POI model. The cy- clicity was appeared in 5 weeks after the POI modeling. The regular 4-day estrous cycle was not recovered, there was a periodic (from 3 to 8 days) appearance in the smear of keratinized cells of the surface epithelium, indicating estrogenic saturation organism. Estrous cycles were observed in $50 \%$ of mice after 8 weeks, which corresponds to the literature data for the used model [8]. Cyclicity was observed in $70 \%$ of females who were injected intraperitoneally with AT MSCs in 8 weeks after chemotherapy. The estrous cycle of animals is recovered about $80 \%$ after AT MSCs injection intraovarially to the 6 th week. The study of sexual activity showed that the number of effective mating of females in 8 weeks after modeling POI was $30 \%$ (Fig. 2, c). This indicator after intraperitoneal injection of AT MSCs was reached 60\%, and after injection of AT MSCs intraovarially was $80 \%$ respectively.

A decrease of the time spent by the animals in the open arm of the elevated plus maze was observed at the studying the behavior of mice in all experimental groups in the anxiolytic test (Fig. 3, a). Zoosocial behavior was changed, females spent less time with another individual in the three-chamber test (Fig. 3, b) comparison with control group. These facts indicated an increase in anxiety in animals in
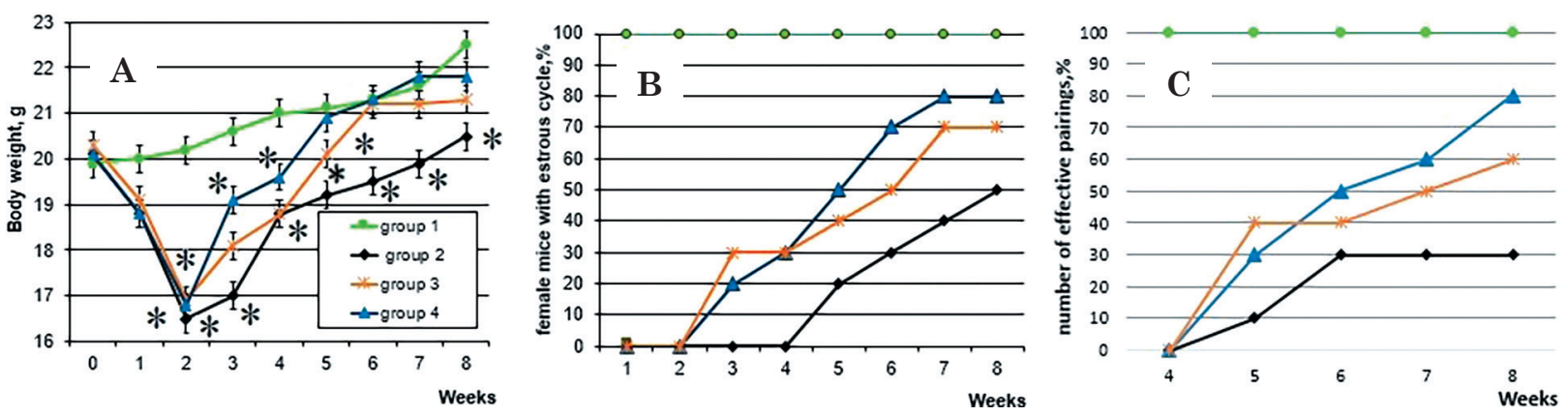

Fig. 2. Dynamics of body weight (a), estrous cycle (b) and sexual activity (c) of animals; * critical level of significance was assumed to be less than $0.05(\mathrm{p}<0.05)$. 

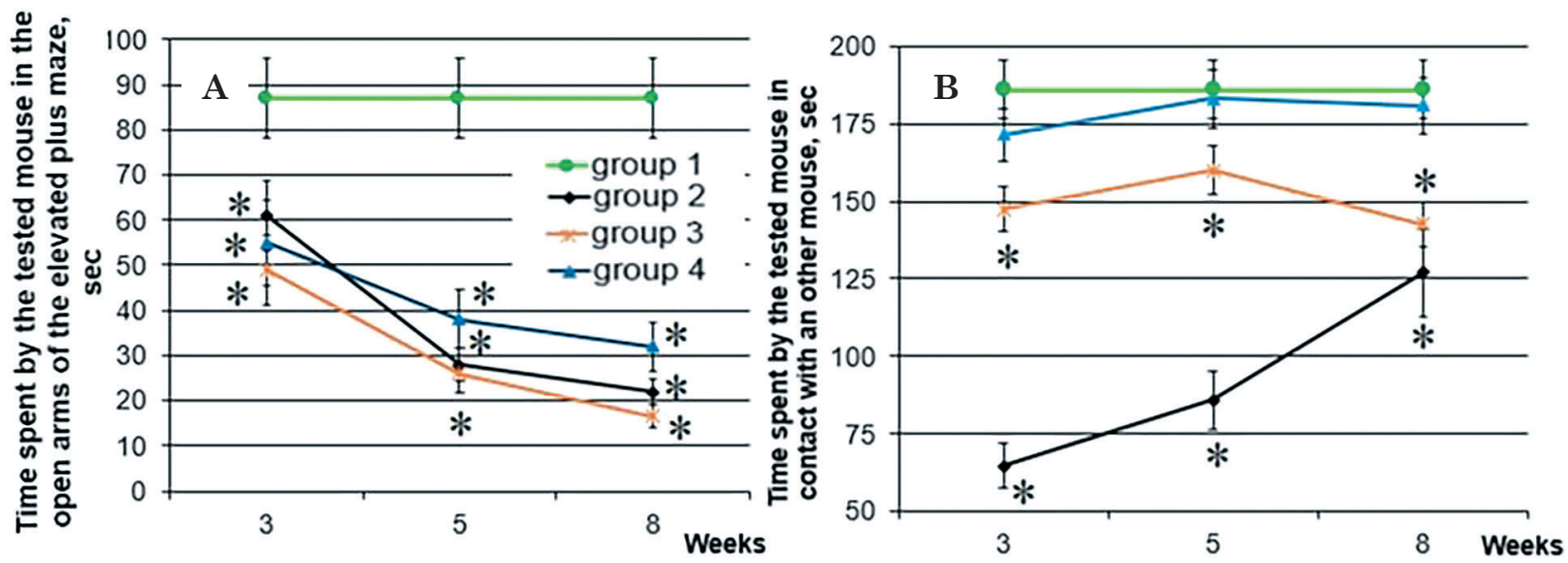

Fig. 3. Change in anxiolytic (a) and zoosocial (b) behavior;

* critical level of significance was assumed to be less than $0.05(\mathrm{p}<0.05)$.
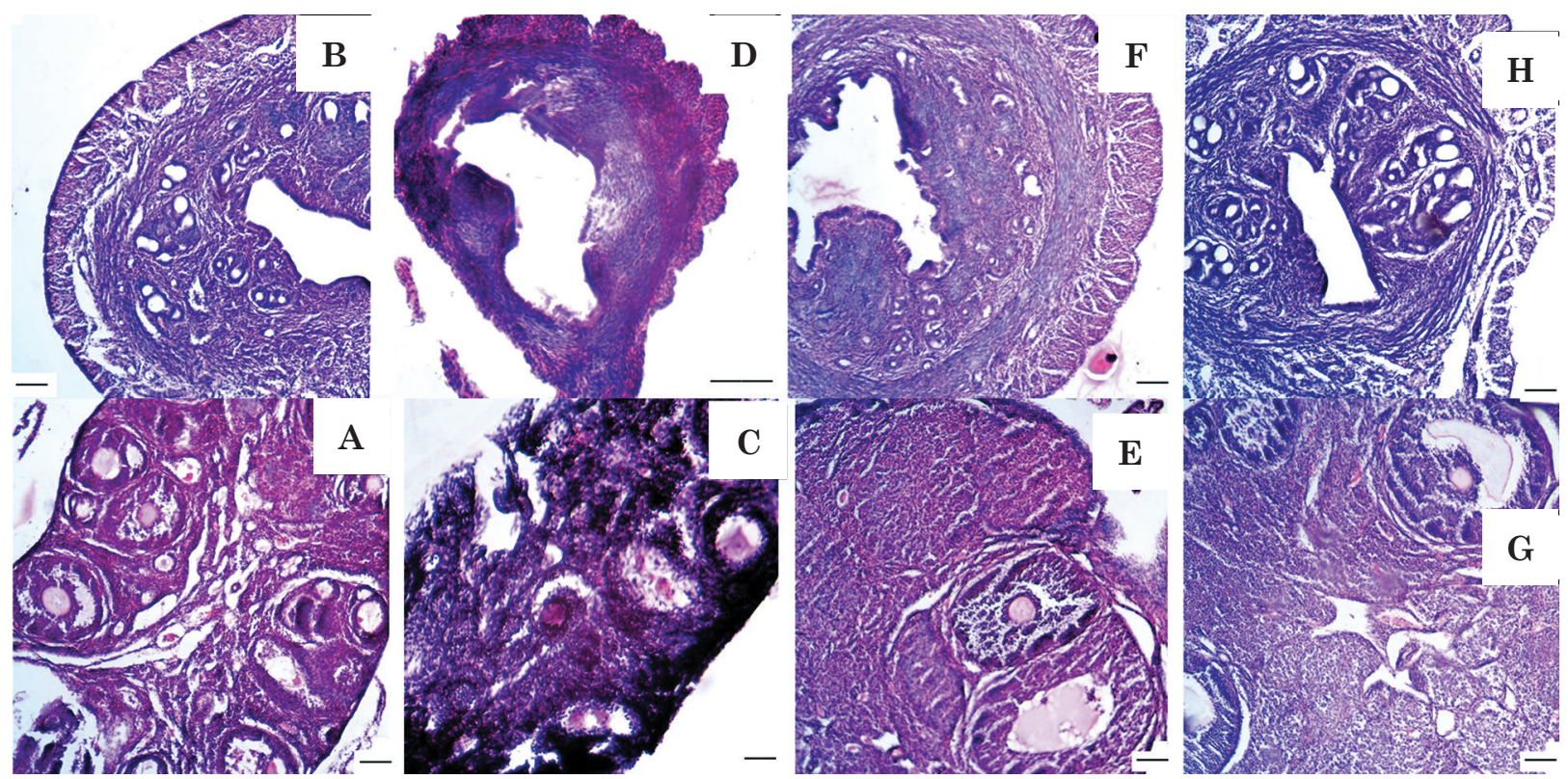

Fig. 4. Morphological changes in the organs of the experimental animals in 8 weeks after POI modeling: b, d, f, h- uterus; a, c, e, g-ovaries; a, b - group 1,

c, $\mathrm{d}$ - group 2 , e, f - group 3, g, h - group 4. Scale bars $100 \mu \mathrm{m}$.

connection with stress caused by exposure to chemotherapeutic drugs, as well as the procedure for introducing AT MSCs.

An increase in animal anxiety was observed in 5 weeks after the POI simulation. The highest increase was observed in the group of mice with the POI model without treatment. Anxiety was increased to a lesser extent after treatment with AT MSCs. Zoosocial behavior in the treated groups was recovered to baseline after 5 weeks. The untreated group of mice shown their recovered zoosocial bihaviour only by the 8th week. The indicator of the anxiolytic test has not reach the initial level in any of the experimental group, however, the least in- crease in anxiety occurred in the group of animals after treatment with intraovarial administration of AT MSCs. It is known that mice in a proestral state spend more time on the open arms of an elevated plus maze than in diestrus. [11]. Thus, the decrease in the time spent by animals on the open arms of the maze after chemotherapy is logically associated with the suppression of the estrogen-producing function of the ovaries and the regulatory system of reproduction in general.

Cytostatic therapy has a proven neurotoxicity: it causes impairment of cognitive functions (memory, attention, coordination), which can persist after the termination of chemotherapy 
and affect the quality of life [12]. We observed only a tendency for the anxiolytic effect of the AT MSCs on the CNS of mice in groups of animals after treatment.

In our opinion, a longer experiment is needed to observe the recovery of behavioral responses associated with the restoration of CNS functions, which occurs slowly after the neurotoxic effects of chemotherapy. However, the indicators of behavioral reactions in animals after intraovarial administration of the AT MSCs, compared to animals injected with the AT MSCs intraperitoneally, improved faster. This fact can be explained by a more effective restoration of ovarian function upon direct administration of the AT MSCs.

Histological examination in animals from the group with the POI model without treatment showed an increase in AT in the abdominal cavity, a decrease in the size of the ovaries, and the absence of structural elements in them: corpus luteum, primordial, primary and secondary follicles; the stroma was filled with large cells (Fig. 4, c).
Thinning of the layers and significant atrophy of the uterine endometrium were observed (Fig. 4, d). Obviously, the restoration of estrogen saturation of the body in the group without treatment occurred at the expense of AT, and not of the ovaries. In animals that were treated with intraperitoneal administration of the AT MSCs, the uterus was morphologically intact, thinning of the layers was present in some places, and slight atrophy of the endometrium was observed (Fig. 4, e). Hyperplasia of single cells or groups of cells, the appearance of structural elements: corpus luteum, primordial and primary follicles were noted in the ovaries (Fig. 4, f). Animals that were treated with intraovarial administration of the AT MSCs, the morphological keeping of the uterus was noted, with slight endometrial hypoplasia in places (Fig. 3, h). Restoration of structural elements: corpus luteum, primordial, primary and secondary follicles was observed in the ovaries (Fig. 3, g), and the number of primary follicles was significantly higher than after intraperitoneal administration of the AT MSCs.

\section{CONCLUSIONS}

1. Treatment of mice with chemotherapyinduced model of POI using AT MSCs has different effectiveness depending on the method of their administration.

2. In the treatment of POI, the intraovarian method of AT MSCs administration provides more rapid and complete restoration of the morphological structure and function of the reproductive system of animals than the intraperitoneal method of administration.

3. The lowest level of anxiety was observed in mice treated with intraovarial administration of AT MSCs, which may be associated with the anxiolytic effect of estrogens with partial restoration of the estrogen-producing ovarian function.

\section{ЛITEPATУРA \\ (REFERENCES)}

1. Na J, Kim GJ. J Ovarian Res 2020; 13(1): 74. doi:10. 1186/s13048-020-00671-2.

2. Ding C, Li H, Wang Y, et al. Stem Cell Res Ther 2017; 8: 173. doi: 10.1186/s13287-017-0613-3.

3. Fenton AJ. J Midlife Health 2015; 6(4): 147-153. doi: 10.4103/0976-7800.172292.

4. Kozub MM, Prokopiuk VY, Skibina KP, et al. Exp Oncol 2017; 39(3): 181-185.

5. Dah-Ching Ding, Woei-Cherng Shyu, Shinn-Zong Lin. Cell Transplant 2011;20(1): 5-14. doi: 10.3727/096368910X.

6. Lelek J, Zuba-Surma EK. Int J Mol Sci 2020; 21(3): 799. doi: 10.3390/ijms21030799.

7. Musatova IB, Volina VV, Chub OV, et al. Neurophysio$\log y 2017$; 49(5): 363-371.
8. Xiao GY, Liu IH, Cheng CC, et al. PLoS One 2014; 9(9). doi: 10.1371/journal.pone.0106538.

9. Sun M, Wang S, Li Y, et al. Stem Cell Res Ther 2013; 4(4): 80. doi: 10.1186/scrt231.

10. Himanshu, Dharmila, Sarkar D, Nutan. Clin Psychopharmacol Neurosci 2020; 18(3): 341-351. doi: 10.9758/ cpn.2020.18.3.341.

11. Heifets BD, Salgado JS, Taylor MD, et al. Sci Transl Med 2019; 11(522): 6435. doi: 10.1126/scitranslmed. aaw6435.

12. Vichaya EG, Chiu GS, Krukowski K, et al. Front Neurosci 2015; 9: 131. doi:10.3389/fnins.2015.00131. 


\section{ПОРІВНЯННЯ ТЕРАПЕВТИЧНИХ ЕФЕКТІВ РІЗНИХ СПОСОБІВ ВВЕДЕННЯ МЕЗЕНХІМАЛЬНИХ СТОВБУРОВИХ КЛІТИН МИШАМ 3 ПЕРЕДЧАСНОЮ НЕДОСТАТНІСТЮ ЯЄЧНИКІВ}

Козуб М. І. ${ }^{1}$, Скибіна К. П. ${ }^{1}$, Мусатова І. Б. ${ }^{2}$, Прокопюк О. В. ${ }^{1}$, Граматюк С. М. ${ }^{1}$, Тининика Л. М. ${ }^{3}$, Козуб М. М. ${ }^{1}$,

Таран А. В. ${ }^{4}$, Нікольченко А. Ю. ${ }^{3}$, Прокопюк О. С. ${ }^{2}$

${ }^{1}$ "Харківська медична академія післядипломної освіти", м. Харків, Україна; 2 «Інститут проблем кріобіології $і$ кріомедицини НАН України», м. Харків, Україна;

${ }^{3}$ ПВНЗ "Харківський міжнародний медичний університет», м. Харків, Україна;

${ }^{4}$ Національний фбармацевтичний університет, м. Харків, Украйна bhbyfq@gmail.com

Передчасна недостатність яечників (ПНЯ) - це стан жіночого гіпогонадизму. Одною з причин розвитку ПНЯ є протипухлинна хіміотерапія. Наразі найбільш ефективним методом лікування ПНЯ вважаеться замісна гормонотерапія, яка, однак, має ряд побічних ефектів, вимагає постійного прийому фармпрепаратів, не забезпечуе відновлення фертильності і корекції патологічних змін органів-мішеней. Тому перспективним є пошук альтернативних методів лікування, заснованих на використанні стовбурових клітин. Метою роботи було порівняння терапевтичних ефектів при різних способах введення мезенхімальних стовбурових клітин, виділених з жирової тканини (МСК ЖТ), у відновленні статевої функції, а також поведінки мишей з ПНЯ, індукованою хіміотерапією.

Матеріали та методи. Дослідження проводили на мишах лінії BALB/c з моделлю ПНЯ, індукованою циклофосфамідом і бусульфаном. Проводили гістологічне дослідження препаратів яечників і маток. Досліджували зміну ваги мишей, функції яєчників, статевої активності, а також поведінки тварин в анксіолітичному та зоосоціальному тестах після лікування МСК ЖТ при інтраперитонеальному та інтраоваріальному способах введення.

Результати та їх обговорення. Показано, що при лікуванні ПНЯ, індукованої хіміотерапією, ефективність застосування МСК ЖТ залежить від способу їх введення. Спостерігалося більш швидке і повне відновлення морфологічної структури, статевої фрункції та поведінкових реакцій у мишей при лікуванні ПНЯ шляхом інтраоваріального введення МСК ЖТ.

К л ючові слов а: передчасна недостатність яєчників, мезенхімальні стовбурові клітини, жирова тканина, хіміотерапія.

\section{COMPARISON OF THERAPEUTIC EFFECTS OF DIFFERENT METHODS OF ADMINISTRATION OF MEZENCHIMAL STEM CELLS TO MICE WITH PREMATURE OVARIAN INSUFFICIENCY}

Kozub M. I. ${ }^{1}$, Skybina K. P. ${ }^{1}$, Musatova I. B. ${ }^{2}$, Prokopiuk O. V. ${ }^{1}$, Gramatiuk S. M. ${ }^{1}$, Tynynyka L. M. ${ }^{3}$, Kozub M. M. ${ }^{1}$, Taran A. V. ${ }^{4}$, Nikolchenko A. Yu. ${ }^{3}$, Prokopiuk O. S. ${ }^{2}$

${ }^{1}$ Kharkiv Medical Academy of Post-Graduate Education, Kharkiv, Ukraine; ${ }^{2}$ Institute for Problems of Cryobiology and Cryomedicine NAS of Ukraine, Kharkiv, Ukraine; ${ }^{3}$ Private institution of higher education "Kharkiv international medical university", Kharkiv, Ukraine; ${ }^{4}$ National University of Pharmacy, Kharkiv, Ukraine bhbyfq@gmail.com

Premature ovarian insufficiency (POI) is condition of female hypogonadism. One of the reasons for the development of POI is anticancer chemotherapy. Currently, hormone replacement therapy is considered the most effective method of treatment POI, which, however, had a number of side effects, requires constant administration of pharmaceuticals, did not restore fertility and correct pathological changes in target organs. Therefore, the search for alternative methods of treatment based on the use of stem cells is promising. The aim of work was to compare the therapeutic effects of different methods of administration of mesenchymal stem cells isolated from adipose tissue (AT MSCs) in restoring sexual function, as well as the behavior of mice with chemotherapy-induced premature ovarian failure.

Materials and methods. The investigation was carried out on BALB/c mice with a POI model induced by Cyclophosphamide and Busulfan. A histological examination of preparations of the ovaries and uterus was carried out. We studied the changes in the weight of mice, ovarian function, sexual activity, as well as the behavior of animals in anxiolytic and zoosocial tests after treatment with AT MSCs with intraperitoneal and intraovarian routes of administration.

Results and discussion. It was shown that the effectiveness of the use of AT MSCs depends on the method of their administration at the treatment of POI induced by chemotherapy. More rapid and complete restoration of the morphological structure, sexual function, and behavioral responses were observed in mice with POI treated by intraovarial administration of AT MSCs.

Key words: premature ovarian insufficiency, mesenchymal stem cells, adipose tissue, chemotherapy. 